\title{
Postoje k pohybovým aktivitám u dívek mladšího školního věku
}

\section{Attitudes toward physical activities by girls in young school age}

\author{
Jakub Holický, Aleš Kaplan, Šárka Honsová
}

Fakulta tělesné výchovy a sportu Univerzity Karlovy v Praze

\begin{abstract}
Abstrakt
Hodnocení postoju $k$ pohybovým aktivitám dètí je aktuálni u nás $i$ v zahraničí. Cílem studie proto bylo provést evaluaci postojů $k$ pohybovým aktivitám u divek mladšího školního věku z Prahy a mimopražského regionu a porovnat výsledky obou skupin pomoci dotazníku CATPA/Grade Year 3. Dotazník postihuje šest dimenzí postoju - sociální cíténí, zdraví, nebezpečí, sociální prožívání, estetično a radost z pohybu.

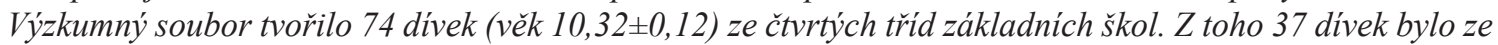
základnich škol v Praze (DP) a 37 divek z mimopražských základnich škol (DM).

Výsledky popsaly postoje divek k pohybovým aktivitám podle jednotlivých dimenzí dotazníku CATPA/Grade Year 3. Komparace výsledků prokázala, že u dimenzi sociálního cítění, zdraví, nebezpeči a radosti z pohybu mají divky (DM) $(M=4,61 ; S D=0,51)$ pozitivnějši postoj $k$ pohybovým aktivitám než divvky (DP) $(M=3,95$; $S D=0,87)$ při stanovené hladině významnosti $p<0,05$. Zjištěné statistické a věcné rozdíly mezi skupinou divek z pražského a mimopražského regionu potvrzuji závěry českých i zahraničnich autorů o postoji dèti k pohybovým aktivitám. Ve volném čase dívek z mimopražského regionu hraje pohybová aktivita důležitějši roli než u jejich vrstevnic z Prahy.
\end{abstract}

\section{Abstract}

The evaluation of attitudes toward physical activity by children is a very discussion issue by us and abroad. The main objective of this study was to determine the attitudes towards physical activities by girls from Prague (DP) and other region (DM) primary schools. The results were compare by both groups with helped the questionnaire CATPA/Grade Year 3. The questionnaire affects six dimensions of attitudes (social sensibilities, health hazards, social perception, aesthetics and the joy of movement).

The research sample consisted of 74 girls (age $=10,32 \pm 0,12)$ from the fourth grade of elementary school. Of that, 37 were girls of primary school in Prague (DP) and the rest 37 girls were from outside Prague's primary school (DM).

The results of the study described the attitude to physical activities girls from Prague and outside Prague elementary school elementary school in each dimension questionnaire CATPA/Grade Year 3. The results were compared. The result demonstrated that the dimensions of social engagement, health, danger and joy of movement girls $(D M)(M=4,61 ; S D=0,51)$ have a more positive attitude towards physical activities than girls (DP) $(M=3,95 ; S D=0,87)$, in determining the significance level of $p<0,05$. This research confirmed conclusion Czech and aboard researchers. The results confirm that girls from primary schools outside Prague have a positive relationship to physical activities than girls from primary schools of Prague.

Klíčová slova: postoje, postojový dotazník, CATPA/Grade Year 3, pohybová aktivita, mladší školní věk

Key words: attitude, attitude questionnaire, CATPA/Grade Year 3, physical activity, young school age

Studie vznikla s podporou projektu Specifického vědeckého výzkumu SVV 2014-260 116, v rámci programu PRVOUK č. 39 Společenskovédní aspekty zkoumání lidského těla a GAUK projekt č. 474214. 


\section{ÚVOD}

Zahraniční i české studie se v současné době velmi věnují problematice postojů k pohybovým aktivitám (dále jen PA) u dětí. Cílem těchto studií jsou komparace mezi skupinami dětí a zjišt’ování signifikantních determinantů při utváŕení samotných postojů (Augustin, Mattocks, Faraway, Greven, \& Ness, 2014; Carson, Rosu, \& Janssen, 2014; Muthuri et al., 2014; Sigmund \& Sigmundová, 2011). Naše studie se zaměřuje na ověřní vlivu prostředí na postoj dívek $\mathrm{k}$ PA.

Pangrazi, Corbin a Welk (1996) definují PA jako komplex lidského chování, které zahrnuje všechny pohybové činnosti člověka a je uskutečňováno zapojením kosterního svalstva.

PA a sport patří k významným atributům životního stylu člověka. Životní styl člověka zahrnuje celistvost norem a hodnot, tělesného, sociálního i mentálního chování jedince měnící se s jeho věkem, pohlavím a kulturním prostředím. Individuální variabilitu v životním stylu podmiňují sociodemografické a psychologické charakteristiky jako věk, pohlaví, socioekonomický status, osobnostní vlastnosti, motivace a postoje subjektu (Bouchard \& Katzmarzyk, 2000).

Na nebezpečí vyplývající z nedostatku pohybové aktivity upozorňují autoři Kučera, Kolář, \& Dylevský (2011), kteří tvrdí, že nedostatek pohybové aktivity u dětí vede v pozdějším věku ke vzniku civilizačních chorob. Na důležitost pohybové aktivity a sportu jako prostředku pro rozvoj osobnosti upozorňuje i Říčan (2006) a Schaal (2014), nebot' pro rozvoj osobnosti jsou patrně nejdůležitější pohybové aktivity v kolektivu.

Čáp (1990) a Sigmundová et al. (2011) zmiňují, že přiměřená PA ovlivňuje faktory zdraví a délky života. Nevhodný způsob využívání volného času bývá zdrojem nepříznivého maladaptivního vývoje a značně přispívá ke vzniku kriminality mladistvých, drogových závislostí a jiných negativních sociálních jevů.

Doporučení WHO (2005) a Afshin et al. (2014) uvádějí, že děti ve školním věku by měly nashromáždit alespoň 60 minut středně až vysoce intenzivní pohybové aktivity denně pro zajištění zdravého rozvoje. WHO (2005) navíc zmiňuje, že děti a mládež potřebují alespoň 20 minut vysoce intenzivní pohybové aktivity 3 krát týdně. Doporučení Richmonda et al. (2014) dále mluví o psychologických a sociálních benefitech doporučované pohybové aktivity. PA zlepšuje u dětí jejich kontrolu nad úzkostí a depresemi. Participace ve skupinových pohybových aktivitách může přispívat $\mathrm{k}$ sociálnímu rozvoji zejména zvyšováním př́ležitostí pro tzv. sebevyjádření, zvyšováním sebevědomí, sociální interakcí a integrací. Dokument také naznačuje, že pohybově aktivní děti mnohem snadněji přijímají další návyky zdravého chování (např. vyhýbání se kouření, alkoholu či drogám) a vykazují lepší studijní výsledky ve škole.

K tomu ovšem př́iliš v dnešní době nedochází. Podle Oktábcové (2007) a Frömela et al. (2002) je jedním $\mathrm{z}$ důvodů negativního postoje $\mathrm{k}$ PA u dětí prostředí, ve kterém dítě vyrůstá.

Rozdíly v PA mezi dětmi z velkých měst a dětmi z vesnic $\mathrm{v}$ jedné z posledních zahraničních studií zmiňuje Bartík (2012). Podle jeho výsledků děti ze základních škol umístěných mimo velké město mají k PA pozitivnější vztah než jejich vrstevníci ze základních škol umístěných ve velkých městech.

\section{CÍL PRÁCE}

Hlavním cílem této studie bylo zjištění postojů $\mathrm{k}$ PA u dívek mladšího školního věku z pražských a mimopražských základních škol a porovnání výsledků obou těchto skupin pomocí dotazníku CATPA/Grade Year 3.

\section{METODIKA}

\section{Výzkumný soubor}

Výzkum byl realizován ve čtvrtých třídách reprezentativně záměrně vybraných ZŠ z pražského a mimopražského regionu. Výzkumný soubor tvořily dívky ze čtvrtých tříd základních škol ( $\mathrm{n}=74$, věk=10,32 $\pm 0,12)$. Z toho 37 dívek bylo ze základní školy v Praze (věk1=10,27 $\pm 0,21$ ) a zbývajících 37 dívek bylo z mimopražské základní školy (věk $2=10,39 \pm 0,21$ ). Konstrukt zkoumaných souborů byl proveden reprezentativně záměrným výběrem podle Pelikána (2011), který byl vymezen demograficky a plnou vybaveností pro tělesnou výchovu ve škole.

Adekvátnost výběru byla velmi podrobně zvažována tak, aby odpovídala reprezentativnosti souboru.

Potřebná data byla získána $\mathrm{v}$ dopoledních hodinách za stejných podmínek u všech probandů. Dívky a jejich zákonní zástupci byli seznámeni s testovacím protokolem a průběhem dotazníkového šetření. Všichni zákonní zástupci dívek podepsali informovaný souhlas $\mathrm{k}$ měření, který byl schválen etickou komisí fakulty tělesné výchovy a sportu Univerzity Karlovy. 


\section{Sběr dat}

Před zahájením dotazování, během něho a při vyhodnocování se vše řídilo přesně danými a popsanými pravidly, aby vypovídající hodnota dotazníku byla co nejvyšší. Samotné vyhodnocování prováděla osoba $\mathrm{k}$ tomu proškolená.

Dotazník CATPA/Grade Year 3 (Schutz, Smoll, Carre, \& Mosher, 1985) je vytvořen ke zjišt’ování, jak se dítě cítí při provádění PA. Standardizaci pro české podmínky provedl Kaplan (2001). Reliabilta testu v metodě split-half se pohybuje v rozmezí 0,80 až 0,90 . Časová náročnost vyplňování dotazníku je 15 až 20 minut. Dotazník je velmi často využíván k zjišt'ování postojů jak u nás, tak v zahraničí (Folsom-Meek, 1992; Holický, 2011; Kaplan, 2001; Patterson \& Faucette, 1990; Smith, 1990; Vachová, 2011).

Otázky v dotazníku nebyly logicky uspořádány. Otázky byly uzavřené. Dotazník byl rozdělen do dvou částí. V první části se zapisoval kód respondenta, v druhé byly otázky, na které respondent odpovídal.

Dotazník je doplněn o manuál, který obsahuje instrukce pro učitele, kteří společně s examinátorem dohlíží na vyplňování dotazníku žáky. Uvedený dotazník postihuje šest dimenzí postojů: Sociální cítění (X1), Zdraví (X2), Nebezpečí (X3), Sociální prožívání (X4), Estetično (X5), Radost z pohybu (X6). Dívky odpovídaly na 6bodové škále s bodovým ohodnocením 0 - nerozumím, 1 - vůbec nebaví, 2 - nebaví, 3 - nejsem rozhodnut, 4 - baví, 5 - hodně baví.

\section{STATISTIKA}

Pro statistické zpracování výzkumných údajů byla využita metoda deskriptivní a induktivní statistiky. Statistika byla zpracována pomocí softwaru NCSS (Trial and Post Trial 2005) a RStudio Version 0.97.551.

Jelikož normalita dat byla prostřednictvím použitých testů (viz Tabulka 1) a grafického zobrazení histogramu (viz Histogram 1) zamítnuta, byly pro zjištění vztahu a rozdílnosti použity neparametrické testy. Stanovili jsme kritérium jak věcné (15\% rozdíl), tak statistické významnosti $\alpha(0,05)$ podle odborné literatury Sun et al. (2013).

Tab. 1: Test normálního rozložení četností proměnné

\begin{tabular}{|l|l|l|l|l|l|}
\hline Testy normality & $\begin{array}{l}\text { Test } \\
\text { hodnoty }\end{array}$ & Level & $\begin{array}{l}\mathbf{1 0 \%} \\
\text { kritická } \\
\text { hodnota }\end{array}$ & $\begin{array}{l}\mathbf{5 \%} \\
\text { kritická } \\
\text { hodnota }\end{array}$ & $\begin{array}{l}\text { Rozhodnutí } \\
\mathbf{0 . 0 5}\end{array}$ \\
\hline \hline Shapiro-Wilk W & 0,8785377 & $3,608191 \mathrm{E}-06$ & 0 & 0 & $\begin{array}{l}\text { Zamítnutí } \\
\text { normality }\end{array}$ \\
\hline Anderson-Darling & 3,290241 & $3,101083 \mathrm{E}-08$ & 0 & 0 & $\begin{array}{l}\text { Zamítnutí } \\
\text { normality }\end{array}$ \\
\hline Martinez-Iglewicz & 0,9735711 & 0 & 1,066685 & 1,103149 & $\begin{array}{l}\text { Zamítnutí } \\
\text { normality }\end{array}$ \\
\hline $\begin{array}{l}\text { Kolmogorov- } \\
\text { Smirnov }\end{array}$ & 0,1736771 & 0 & 0,094 & 0,102 & $\begin{array}{l}\text { Zamítnutí } \\
\text { normality }\end{array}$ \\
\hline $\begin{array}{l}\text { D'Agostino } \\
\text { Skewness }\end{array}$ & $-1,307563$ & 0,1910215 & 1.645 & 1.960 & $\begin{array}{l}\text { Zamítnutí } \\
\text { normality }\end{array}$ \\
\hline D'Agostino Kurtosis & $-2,7683$ & 0,005636 & 1.645 & 1.960 & $\begin{array}{l}\text { Zamítnutí } \\
\text { normality }\end{array}$ \\
\hline $\begin{array}{l}\text { D'Agostino } \\
\text { Omnibus }\end{array}$ & 9,3730 & 0,009219 & 4.605 & 5.991 & $\begin{array}{l}\text { Zamítnutí } \\
\text { normality }\end{array}$ \\
\hline
\end{tabular}

Pro stanovení významnosti rozdílu mezi oběma použitými formami testu byl využit Mann-Whitney test pro neparamatrické hodnoty dvou a více nezávislých. Tento test ověruje hypotézu H0. Při zamítnutí hypotézy H0 v hladině významnosti $\mathrm{p}<0,05$ použijeme alternativu parametrického multikomparativního Duncan testu. Tedy Behrens-Fisher neparametrický t-test, který vyjádříme jak číselně, tak graficky. Interval spolehlivosti bude stanoven na hladině 0,95 podle Hendla (2006) a Chrásky (2007). Výsledky jsou prezentovány ve formě tabulek a grafü. 
Histogram 1: Test normality rozložení dat

\section{Histogram}

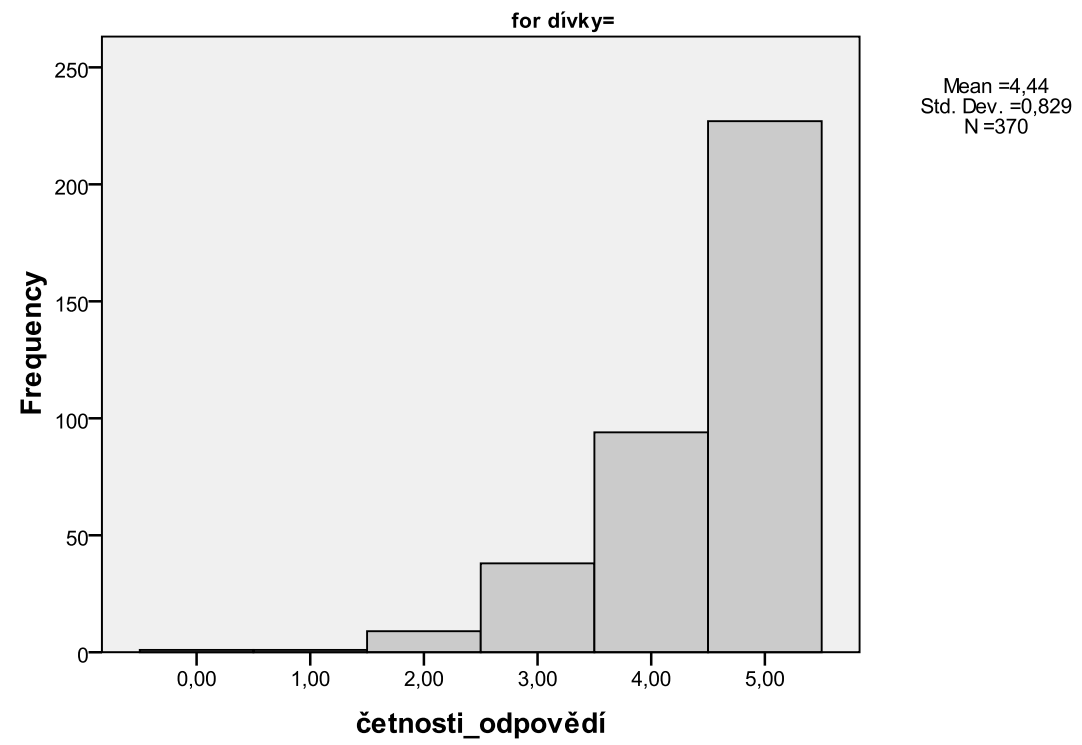

\section{VÝSLEDKY A DISKUZE}

V tabulce 2 jsou uvedeny průměrné hodnoty, mediány a směrodatné odchylky u jednotlivých dimenzí dotazníku CATPA/Grade Year 3 u obou skupin dívek DM a DP. Dívky odpovídaly na 6bodové škále, která měla bodové ohodnocení 0 - nerozumím, 1 - vůbec nebaví, 2 - nebaví, 3 - nejsem rozhodnut, 4 - baví, 5 - hodně baví. U žádné otázky nebyla zaznamenána odpověd' s hodnotou nula, tedy že proband dané otázce nerozuměl. Lze konstatovat, že otázky jsou jasné a srozumitelné, což potvrdila i standardizace provedená Kaplanem (2001). Faktorová analýza dotazníku zároveň potvrdila dimenzionální rozdělení jednotlivých oblastí. Tedy každá otázka popisuje přesně svou oblast. Hodnoty v tabulce 2 informují, jaký postoj zaujímají dívky k jednotlivým oblastem PA. Čím vyšší hodnota je zaznamenána u jednotlivých dimenzí, tím pozitivnější vztah má proband $\mathrm{k}$ dané oblasti.

Tab. 2: Statistická charakteristika pro jednotlivé dimenze u divek z Prahy a mimopražských dívek

\begin{tabular}{|c|c|c|c|c|c|c|}
\hline \multirow{2}{*}{ Dimenze } & \multicolumn{3}{|c|}{ Dívky mimopražské (DM) } & \multicolumn{3}{|c|}{ Dívky Praha (DP) } \\
\cline { 2 - 7 } & $\mathrm{M}$ & Průměr & SD & M & Průměr & SD \\
\hline Sociální cítění (X1) & 5 & 4,57 & 0,60 & 3 & 2,65 & 0,82 \\
\hline Zdraví (X2) & 5 & 4,51 & 0,65 & 4 & 4,08 & 0,82 \\
\hline Nebezpečí (X3) & 5 & 4,68 & 0,47 & 4 & 4,16 & 0,86 \\
\hline Sociální prožívání (X4) & 5 & 5 & 0 & 5 & 4,95 & 0,22 \\
\hline Estetično (X5) & 5 & 4,65 & 0,58 & 5 & 4,19 & 1,17 \\
\hline Radost z pohybu (X6) & 5 & 4,65 & 0,53 & 3 & 3,57 & 1,04 \\
\hline
\end{tabular}

Vysvětlivky: M=medián $S D=$ směrodatná odchylka 
V tabulce 2 je názorně vidět, že DM ve všech dimenzích zaujímají pozitivnější vztah k PA oproti svým vrstevnicím DP. Největší rozdíl průměrných hodnot a mediánů je zaznamenán u dimenzí X1 - Sociální cítění a X6 - Radost z pohybu. V př́padě dimenze X4 - Sociální prožívání byla u dívek (DM) průměrná hodnota odpovědi 5. Zásadní vliv na výsledky může mít v tomto př́ípadě podle Oktábcové (2007) a Frömla et al. (2002) prostředí, ve kterém dítě vyrůstá. Zatímco pro DM představuje PA hlavní volnočasový zájem, u DP vystupují jiné zájmy.

Pro potvrzení, zda rozdíly změřené mezi DM a DP jsou statisticky významné, byl využit neparametrický test Mann-Whitney pro dva nezávislé výběry. Jedná se o obdobu analýzy rozptylu pro ordinální proměnné nebo pro kardinální proměnné, kde se rozptyly ve skupinách výrazně liší. Při teoretickém výpočtu se hodnota testového kritéria porovnává s tabulkou normálního rozdělení nebo kvantity v přesných tabulkách. Ověřujeme tak, zda rozdíl je statisticky významný, tedy že máme zamítnout hypotézu H0. V tabulce 3 jsou uvedeny výsledky tohoto testu pro jednotlivé dimenze. Zatímco u dimenzí Sociální cítění (X1), Zdraví (X2), Nebezpečí (X3) a Radost z pohybu (X6) z výsledků vyplývá p<0,05, tedy že rozdíl je statisticky významný. U dimenzí Sociální proživání (X4) a Estetično (X5) výsledek byl vyjádřen hodnotou p>0,05, přijímáme hypotézu H0.

Tab. 3: Mann-Whitney test u divek z Prahy a mimo Prahu

\begin{tabular}{|c|c|c|c|}
\hline \multicolumn{4}{|c|}{ Mann-Whitney test } \\
\hline Dimenze & Mann-Whitney chi-squared & df & p-value \\
\hline Sociální cítění (X1) & 49.1263 & 1 & $2.4 \mathrm{e}-12$ \\
\hline Zdraví (X2) & 5.521 & 1 & 0.01879 \\
\hline Nebezpečí (X3) & 7.5915 & 1 & 0.005864 \\
\hline Sociální prožívání (X4) & 2.0278 & 1 & 0.1544 \\
\hline Estetično (X5) & 3.0778 & 1 & 0.07937 \\
\hline Radost z pohybu (X6) & 21.2373 & 1 & $4.058 \mathrm{e}-06$ \\
\hline
\end{tabular}

Vysvětlivky: $d f=$ stupně volnosti

Tabulka 4 prezentuje výsledky následujícího multikomparativního testu Behrens-Fisher. Mnohonásobné porovnávání umožňuje stanovení statistické významnosti u jednotlivých rozdílů středních hodnot u všech možných párů porovnávaných skupin.

Tab. 4: Neparametrický test Behrens-Fisher s intervalem spolehlivosti $95 \%$ u divek z Prahy a mimo Prahu

\begin{tabular}{|c|c|c|c|c|c|}
\hline \multicolumn{7}{|c|}{ Neparametrický Test Behrens-Fisher } \\
\hline Dimenze & Estimator & Dolní mez & Horní mez & T & p-value \\
\hline Sociální cítění (X1) & 0.042 & 0.017 & 0.091 & -8.494 & 0 \\
\hline Zdraví (X2) & 0.354 & 0.247 & 0.475 & -2.356 & 0.018 \\
\hline Nebezpečí (X3) & 0.334 & 0.233 & 0.449 & -2.786 & 0.005 \\
\hline Radost z pohybu (X6) & 0.209 & 0.125 & 0.318 & -4.693 & 0 \\
\hline
\end{tabular}

Vysvětlivky: Estimator=odpovídající efekt T=test statistic 
Výsledky v tabulce 4 potvrzují, že rozdíly mezi skupinami DM a DP v dimenzích Sociální cítění (X1), Zdraví (X2), Nebezpečí (X3) a Radost z pohybu (X6) jsou statisticky významné na hladině p<0,05.

Skupina DM v tomto prrípadě má pozitivnější vztah $\mathrm{k}$ PA v uvedených dimenzích oproti vrstevnicím ze skupiny DP.

\section{$95 \%$ Confidence Interval for $\mathrm{p}$ Method: Probit - Transformation}

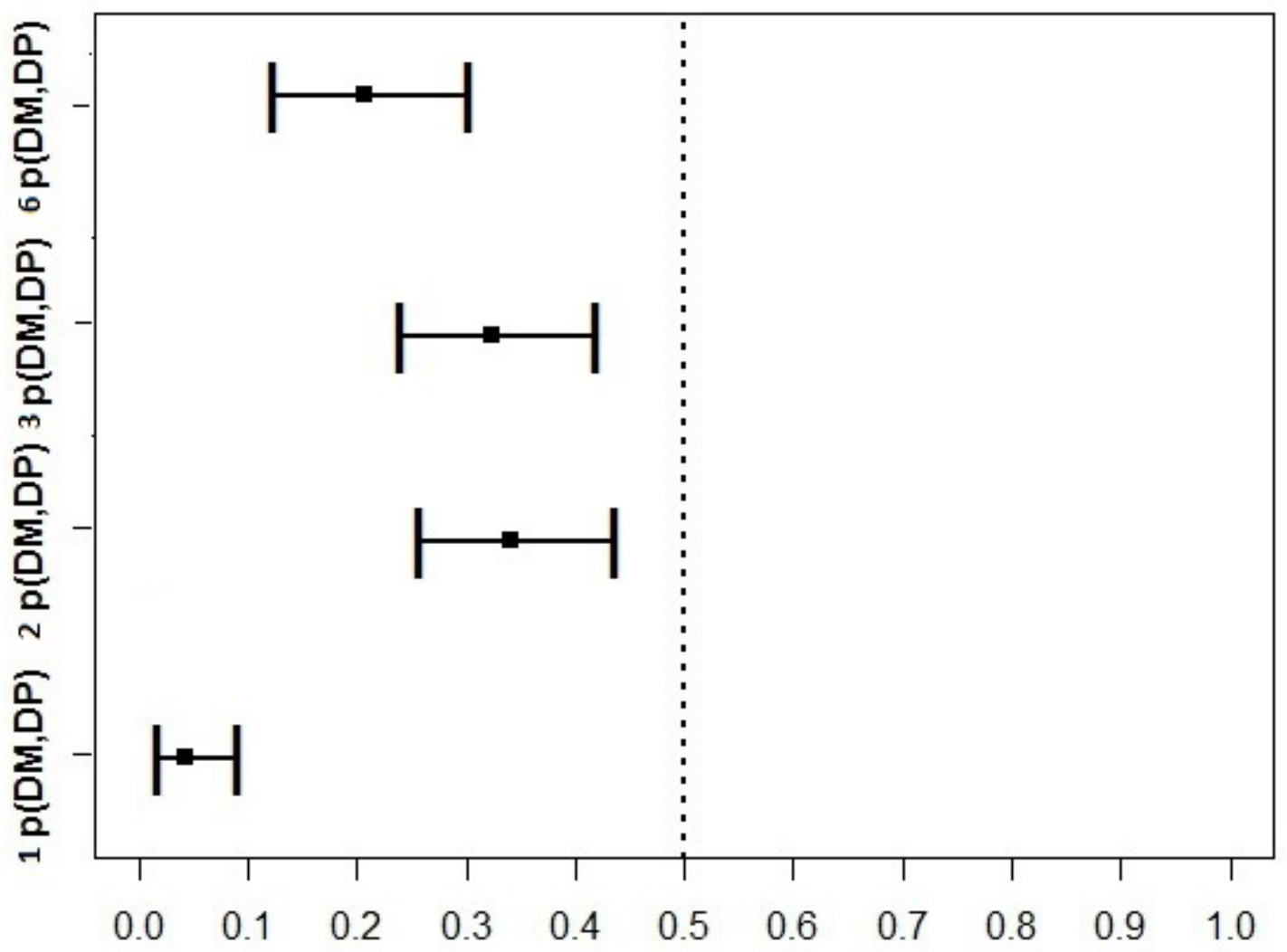

Obr. 3: Grafické zobrazení neparametrického testu Behrens-Fisher test na hladině spolehlivosti 95 \% mezi DM a DP u dimenze X1(sociální cítění), dimenze X2(zdraví), dimenze X3(nebezpečí) a dimenze X6(radost z pohybu)

Vysvětlivky: $1 p(D M, \quad D P)=$ dimenze X1(sociální cítění); $2 p(D M, D P)=$ dimenze $X 2(z$ draví); $3 p(D M$, $D P)=$ dimenze $X 3$ (nebezpeči $) ; 6 p(D M, D P)=$ dimenze $X 6($ radost $z$ pohybu)

Grafické vyjádření tohoto vztahu s intervalem spolehlivosti 95 \% a znázorněnou hladinou významnosti 0,05 pro jednotlivé dimenze jsou uvedeny na obrázku 1, pro dimenzi Sociální cítění (X1), dimenzi Zdraví (X2), dimenzi Nebezpečí (X3) a pro dimenzi Radost z pohybu (X6).

\section{ZÁVĚR}

Cílem této studie bylo zjistit postoje $\mathrm{k}$ PA u dívek mladšího školního věku z pražského (DP) a mimopražského regionu (DM) a následně porovnat výsledky obou skupin pomocí dotazníku CATPA/Grade Year 3.

Předpokládáme, že jedním z hlavních determinantů, který ovlivňuje postoj dětí k PA, je prostředí, ve kterém dítě vyrůstá. Proto jsme se rozhodli porovnat dvě skupiny probandů z různých regionů České republiky. Výsledky studie potvrdily tvrzení Bartíka (2012), že děti žijící mimo velká města mají k PA pozitivnější postoj než jejich vrstevníci z velkých měst.

Ve všech dimenzích dotazníku CATPA/Grade Year 3 skupina dívek (DM) měla pozitivnější postoj k PA než skupina dívek (DP) z Prahy. Statisticky významný rozdíl se podařilo prokázat v dimenzích Sociálního 
cítění (X1), Zdraví (X2), Nebezpečí (X3) a Radosti z pohybu (X6), kde byla hodnota rozdílu p <0,05 ověřena pomocí neparametrických testů. U těchto dimenzí měla skupina dívek (DM) pozitivnější postoj k PA než jejich vrstevnice z Prahy. U dimenzí Sociální prožívání (X4) a Estetično (X5) byl výsledek vyjádřen hodnotou p>0,05, tedy rozdíl nebyl signifikantně významný.

Domníváme se, že jedním z faktorů, který ovlivňuje postoje $\mathrm{k}$ PA, je postavení sportu v rámci volnočasové aktivity dětí. V oblasti menších měst zůstává PA hlavní volnočasovou aktivitou. V případě velkých měst se objevuje celá řada dalších volnočasových aktivit. Právě to způsobuje, že děti nemají takový zájem o PA. Bylo by vhodné naši studii rozšířit a doplnit o další determinanty, které mohou ovlivnit utváření postojů $\mathrm{k}$ PA. Ze získaných výsledků můžeme poté vyvodit vhodná doporučení ke zlepšování postojů k PA dětí.

\section{LITERATURA}

Afshin, A., Micha, R., Khatibzadeh, S., Schmidt, L. A., \& Mozaffarian, D. (2014). Dietary Policies to Reduce Non-Communicable Diseases. The Handbook of Global Health Policy, 175-193.

Augustin, N. H., Mattocks, C., Faraway, J. J., Greven, S., \& Ness, A. R. (2014). Modelling a response as a function of high frequency count data: the association between physical activity and fat mass. arXiv preprint arXiv:1401.4342.

Bartík, P. (2012). Primary School Students' Attitudes Towards Physical Education and Sports in Central Slovak Region. European researcher, 32(10-2), 1788-1791.

Bouchard, C., \& Katzmarzyk, P. (2000). Physical Activity and Obesity. Human Kinetics.

Carson, V., Rosu, A., \& Janssen, I. (2014). A cross-sectional study of the environment, physical activity, and screen time among young children and their parents. BMC public health, 14(1), 61.

Chráska, M. (2007). Metody pedagogického výzkumu: Grada Publishing as.

Č́a, J. (1990). Psychologie mnohostranného vývoje člověka. Státní pedagogické nakladatelství.

Folsom-Meek, S. L. (1992). A Comparison of Upper Elementary School Children's Attitudes toward Physical Activity. ERIC.

Frömel, K., Formánková, S., \& Sallis, J. F. (2002). Physical activity and sport preferences of 10 to 14 year old children: A 5 year prospective study. Acta Universitatis Palackianae Olomucensis. Gymnica, 32(1), 11-16.

Hendl, J. (2006). Přehled statistických metod zpracování dat: analýza a metaanalýza dat: Portál.

Holický, J. (2011). Postoje k pohybovým aktivitám u žáků mladšiho školního věku. (Diplomová práce), UK FTVS, Praha.

Kaplan, A. (2001). Identifikace pohybově indisponovaného žáka a studium jeho role v podmínkách školní tělesné výchovy. (Disertační práce), UK FTVS, Praha.

Kučera, M., Koláŕ, P., \& Dylevský, I. (2011). Ditě, sport a zdraví. Galén.

Muthuri, S. K., Wachira, L.-J. M., Leblanc, A. G., Francis, C. E., Sampson, M., Onywera, V. O., \& Tremblay, M. S. (2014). Temporal trends and correlates of physical activity, sedentary behaviour, and physical fitness among school-aged children in Sub-Saharan Africa: a systematic review. International journal of environmental research and public health, 11(3), 3327-3359.

Oktábcová, J. (2007). Pohybové aktivity dětí v předškolním a mladším školním věku. (Diplomová práce), UK FTVS, Praha.

Pancrazi, R. P., Corbin, C. B., \& Welk, G. J. (1996). Physical activity for children and youth. Journal of Physical Education, Recreation \& Dance, 67(4), 38-43.

Patterson, P., \& Faucette, N. (1990). Children's attitudes toward physical activity in classes taught by specialist versus nonspecialist PE teachers. Journal of teaching in physical education.

Pelikán, J. (2011). Základy empirického výzkumu pedagogických jevů. Karolinum.

Richmond, R. C., Smith, G. D., Ness, A. R., den Hoed, M., McMahon, G., \& Timpson, N. J. (2014). Assessing Causality in the Association between Child Adiposity and Physical Activity Levels: A Mendelian Randomization Analysis. Plos medicine, 11(3), 100-116.

Říčan, P. (2006). Cesta životem. Vývojová psychologie. Přepracované vydání: Portál.

Schaal, S. (2014). Becoming a Health-Promoting School: Effects of a 3-Year Intervention on School Development and Pupils Topics and Trends in Current Science Education (pp. 435-452): Springer.

Schutz, R. W., Smoll, F. L., Carre, F. A., \& Mosher, R. E. (1985). Inventories and norms for children's attitudes toward physical activity. Research Quarterly for exercise and sport, 56(3), 256-265.

Sigmund, E., \& Sigmundová, D. (2011). Pohybová aktivita pro podporu zdraví dětí a mládeže. Univerzita 
Palackého v Olomouci.

Sigmundová, D., El Ansari, W., \& Sigmund, E. (2011). Neighbourhood environment correlates of physical activity: a study of eight Czech regional towns. International journal of environmental research and public health, 8(2), 341-357.

Smith, S. W. (1990). Comparison of individualized education programs (IEPs) of students with behavioral disorders and learning disabilities. The Journal of Special Education, 24(1), 85-100.

Sun, Y., Paulus, D., Eyssen, M., Maervoet, J., \& Saka, O. (2013). A systematic review and meta-analysis of acute stroke unit care: What's beyond the statistical significance? BMC medical research methodology, 13(1), 132.

Vachová, K. (2011). Názory a postoje pohybově neúspěšných žáků mladšího školního věku k pohybovým aktivitám. (Diplomová práce), UK FTVS, Praha.

WHO. (2005). Preventing Chronic Diseases. A Vital Investment. World Health Organization. 